\title{
NEOAPOCREADIUM CHABAUDI SP. N. (APOCREADIIDAE) AND SCHIKHOBALOTREMA ACUTA (LINTON, 1910) (HAPLOSPLANCHNIDAE) TREMATODES PARASITES OF MARINE FISHES IN BRAZIL ${ }^{1}$
}

\author{
A. KOHN and B. M. M. FERNANDES*
}

\begin{abstract}
SUMMARY. Neoapocreadium chabaudi sp. n. (Digenea, Apocreadiidae) is described from the intestine of a marine fish Stephanolepis hispidus from Brazil, and the genus Schikhobalotrema Skrjabin \& Guschanskaja, 1955 represented by its type species S. acuta (Linton, 1910) Skrjabin and Guschanskaja, 1955, is for the first time reported from the intestine of Strongylura marina in Brazil.

$N$. chabaudi sp. n. is more closely related to $N$. angustum (Sogandares-Bernal, 1959) from which differs mainly in the size of the eggs, by the presence of intercecal vitelline follicles in the region between the testes and acetabulum, and by the large genital atrium.
\end{abstract}

\section{Neoapocreadium chabaudi sp. n. (Apocreadiiae) et Schikhobalotrema acuta (Linton, 1910) (Haplosplanchnidae) Trématodes parasites de poissons marins du Brésil.}

RÉSUMÉ. Neopocreadium chabaudi sp. n. est décrit de l'intestin d'un poisson marin Stephanolepis hispidus du Brésil, et le genre Schikhobalotrema Skrjabin and Guschanskaja, 1955, représenté par l'espèce type $S$. acuta (Linton, 1910) est, pour la première fois, signalé au Brésil.

$N$. chabaudi sp. n. est très proche de $N$. augustum (Sogandares-Bernal, 1959). Il s'en distingue surtout par la grandeur des œufs, par la présence de follicules vitellogènes intercaecaux entre les testicules et l'acétabulum, et par le grand atrium génital.

\section{Introduction}

From 1923 to 1925 Travassos worked in a Health Service Program in Angra dos Reis (Rio de Janeiro, Brazil) and published many papers on the local helminthological fauna, but some of the samples have not been determined as yet. In this paper, two trematodes collected in this period are studied.

\footnotetext{
* Departamento de Helmintologia, Instituto Oswaldo Cruz, C.P. 926, Rio de Janeiro, R.J., Brasil. I. Supported in part by the Conselho Nacional de Desenvolvimento Científico e Tecnológico (CNPq), Brasil.

Accepté le I2 août I98I.
} 
The parasites preserved in Railliet and Henry's fluid were stained in alcoholicacid carmine, dehydrated in EtOH, cleared in Faia's creosote and mounted in Canada balsam. The illustration was made with the aid of a drawing tube; measurements are in millimeters.

\section{Neoapocreadium chabaudi sp. n.}

(fig. 1, 2, 3)

Host: Stephanolepis hispidus (L., 1758) (= Monacanthus hispidus).

Habitat: Intestine.

Locality: Angra dos Reis, Rio de Janeiro, Brazil.

Material: Holotype no 31.813-b and paratype no 31.813-a deposited in the Helm. Coll. of the Oswaldo Cruz Institute.

Description based on two mature specimens.

Body elongated, spined, rounded at both ends, 7.50 to 7.90 in length and 1.50 to 1.71 in width. Oral sucker 0.75 to 0.77 long by 0.52 to 0.62 wide, subterminal, elliptical, with longitudinal slitlike opening. Prepharynx 0.32 to 0.34 long. Muscular pharynx 0.43 to 0.48 long by 0.44 to 0.50 wide, with a band of circular muscles in the anterior end. Esophagus short. Caeca long extending almost to posterior end of body, ending blindly. Acetabulum pre-equatorial, 0.55 to 0.65 long by 0.55 to 0.60 wide. Sucker ratio $1: 1,01-1: 1,26$. Genital pore median, immediately preacetabular. Genital atrium oval, 0.15 to 0.21 long by 0.11 to 0.12 wide immediately pre-acetabular. Testes tandem, close together, inter-cecal, post-equatorial and postovarian; anterior testis 0.67 to 0.69 long by 0.51 to 0.56 wide, posterior testis more elongated 0.75 to 0.86 long by 0.52 to 0.53 wide. Cirrus and cirrus-sac absent. Seminal vesicle saccular 0.76 long by 0.28 to 0.33 wide, extending from posterior half of acetabulum to anterior ovarian zone; ejaculatory duct relatively long, thin walled, opening into the genital atrium. Ovary globular, smooth, submedian, 0.36 to 0.37 long by 0.30 to 0.34 wide, post-acetabular and pre-testicular, separated from anterior testis by the Mehlis' gland. Seminal receptacle extending anterior to ovary, 0.32 to 0.48 long by 0.18 to 0.19 wide. Laurer's canal present. Vitellaria with numerous follicles extending from the level of the intestinal bifurcation to the posterior end of the body; they are confluent anterior to the acetabulum and posterior to the testes, with extra-cecal, cecal and intercecal follicles in the region between the acetabulum and the testes. Uterus pretesticular passing along righ side of acetabulum. Eggs operculated with 0.078 to 0.086 long by 0.050 to 0.054 wide, some with very small knob at one end (fig. 3). Lymphatic channels present. 

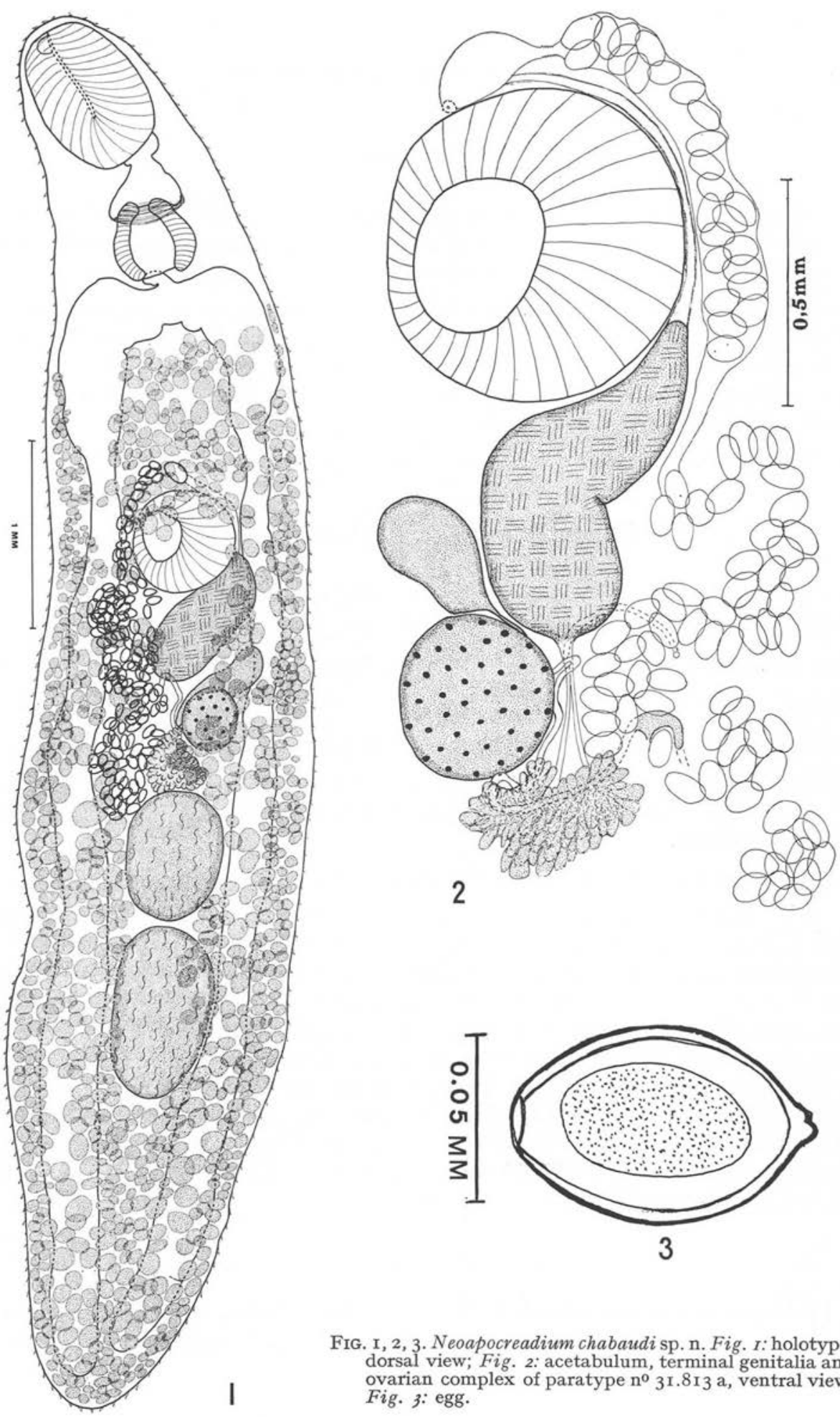

FIG. I, 2, 3. Neoapocreadium chabaudi sp. n. Fig. I: holotype, dorsal view; Fig. 2: acetabulum, terminal genitalia and ovarian complex of paratype $\mathrm{n}^{0} 31.813 \mathrm{a}$, ventral view; Fig. 3: egg. 


\section{Discussion}

The genus Neoapocreadium was erected by Siddiqi and Cable (1960) for the species $N$. angustum, $N$. bravoi and $N$. coili described by Sogandares-Bernal (1959). In 1965, Fischthal and Kuntz added another species to this genus: N. malaysiae.

Neoapocreadium chabaudi sp. n. is more closely related to $N$. angustum from which differs mainly in the size of the eggs ( 0.078 to 0.086 long by 0.050 to 0.054 wide in the new species and 0.060 to 0.074 by 0.011 to 0.014 in $N$. angustum) by the presence of intercecal vitelline follicles in the region between the testes and the acetabulum and by the presence of a genital atrium.

The new species is named in honor of Prof. Alain Chabaud.

\section{Schikhobalotrema acuta (Linton, 1910)}

Skrjabin and Guschanskaja, 1955

(fig. 4-5)

Host: Strongyhra marina (Walbaum, 1792) (= Tylosurus marinus).

Habitat: Intestine.

Locality: Angra dos Reis, Rio de Janeiro, Brazil (new locality record).

Material: Specimens preserved in balsam no $31.814-\mathrm{a}-\mathrm{e}, 31.876-\mathrm{a}-\mathrm{d}$ and in Railliet and Henry's fluid no 4.866, 5.707 deposited in the Helm. Coll. of the Oswaldo Cruz Institute.

Measurements based on 7 specimens from 23.

Body 1.68 to 2.67 long by 0.71 to 0.94 wide. Oral sucker 0.19 to 0.31 long by 0.19 to 0.29 wide. Ventral sucker 0.31 to 0.45 long by 0.32 to 0.48 wide with longitudinal aperture and a pair of developed finger-like lateral lobes on each side. Sucker ratio $1: 1,5$ to $1: 1,7$. Short prepharynx; pharynx 0.11 to 0.14 long by 0.10 to 0.16 wide; short esophagus; single cecum may extend to midtestis. Genital pore median or submedian, opposite posterior end of pharynx. Ovary 0.15 to 0.21 long by 0.12 to 0.22 wide. Seminal receptacle 0.20 to 0.38 long by 0.10 to 0.19 wide. Testes 0.37 to 0.55 long by 0.20 to 0.33 wide. Seminal vesicle 0.78 to 1.03 long by 0.09 to 0.11 wide. Genital atrium large, with two groups of tubular structures, probably prostatic cells, not easily evidentiated in all specimens. Uterus with few eggs (5 to 17), 0.080 to 0.094 long by 0.054 to 0.070 wide.

\section{REMARKS}

This species was redescribed by Manter (1937), Caballero and col. (1953) and Pérez Vigueras (1956), and revised by Sogandares (1959) and Sogandares and Sogan- 

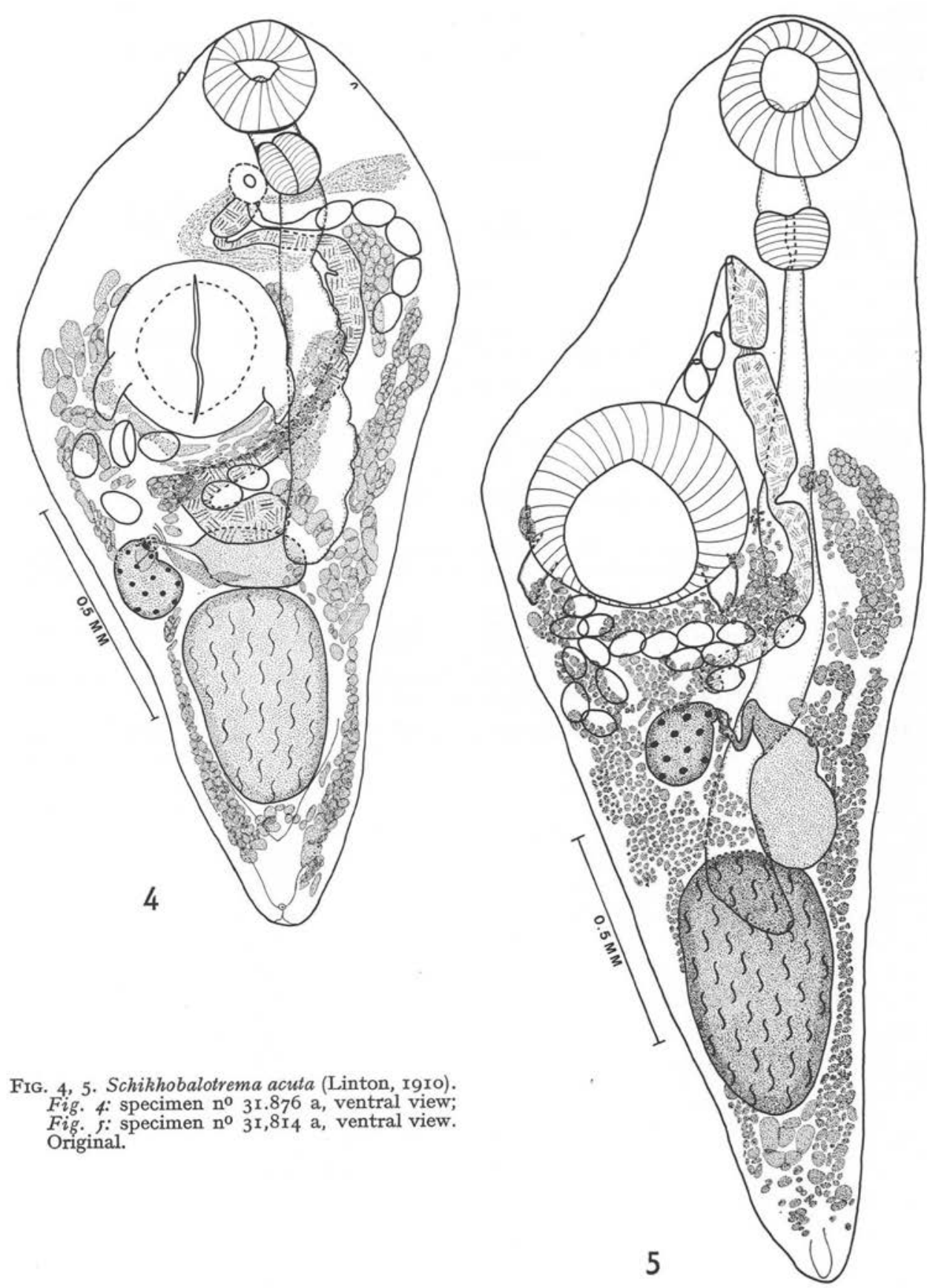

FIG. 4, 5. Schikhobalotrema acuta (Linton, 1910). Fig. 4: specimen no $3 \mathrm{r} .876$ a, ventral view; Fig. s: specimen $\mathrm{n}^{0} 3 \mathrm{I}, 8 \mathrm{I} 4$ a, ventral view. Original. 
dares (1961). Overstreet (1969) described for the first time the tubular structures of the genital bulb. In this opportunity the first occurence of this genus in Brazil is reported.

\section{REFERENCES}

Caballero y C. E., Bravo-Hollis M., Grocott R. G.: Helmintos de la República de Panama. VII. Descripción de algunos tremátodos de peces marinos. An. Inst. Biol. Méx., 1953, 24, 97-136.

Fischthal J. H., Kuntz R. E.: Digenetic trematodes of fishes from North Borneo (Malaysia). Proc. helm. Soc. Wash., I965, 32, 63-71.

MANTER H. W.: The status of the trematode genus Deradena Linton with a description of six species of Haplosplanchnus Looss. Skrjabin Jubil., 1937, 381-387.

Overstreet R. M.: Digenetic trematodes of marine teleost fishes from Biscayne Bay, Florida. Tulane Stud. Zool., 1969, Is, I19-176.

Pérez Vigueras I.: Contribucion al conocimiento de la fauna helmintologica Cubana. Mem. Soc. Hist. Nat., 1956, 23, 1-36.

Siddigr A. H., Cable R. M.: Digenetic trematodes of marine fishes of Puerto Rico. N. Y. Acad. Sci., 1960, 17, 257-369.

SkRJABIN K. I., Guschanskaja L. H.: Hemiurata (Markevitsch, 195I) In: Skrjabin K. I. Tratado de Trematodologia, Trematódeos dos animais e do homem, 10, 1-653. Akad. Nauk. SSSR, Moscou, 1955.

Sogandares-Bernal F.: Digenetic trematodes of marine fishes from the Gulf of Panama and Bimini, British West Indies. Tulane Stud. Zool., I959, 7, 69-II 7.

Sogandares-Bernal F., Sogandares M. L.: Nine digenetic trematodes of marine fishes from the Atlantic coast of Panama. Tulane Stud. Zool., I961, 8, 141-153.

Travassos L.: Pesquizas scientificas realisadas em Angra dos Reis, I. A Folha Medica., 1924, S, I $52-153$. 